М. М. Рожко, Г. М. Ерстенюк, В. В. Капечук, М. О. Іванців, С. М. Луцак, В. В. Дзвонковська, В. М. Сенчій

Державний вищий навчальний заклад “Івано-Франківський національний медичний університет”, м. Івано-Франківськ

\title{
СУЧАСНІ ПІДХОДИ ДО ФОРМУВАННЯ ВИСОКОПРОФЕСІЙНОГО ВИКЛАДАЧА В ІВАНО-ФРАНКІВСЬКОМУ НАЦІОНАЛЬНОМУ МЕДИЧНОМУ УНІВЕРСИТЕТІ
}

\author{
M. M. Rozhko, H. M. Ersteniuk, V. V. Kapechuk, M. O. Ivantsiv, S. M. Lutsak, \\ V. V. Dzvonkovska, V. M. Senchii \\ State Higher Educational Institution “Ivano-Frankivsk National Medical University”, \\ Ivano-Frankivsk
MODERN APPROACHES TO THE FORMATION OF A HIGHLY PROFESSIONAL INSTRUCTORS AT IVANO-FRANKIVSK NATIONAL MEDICAL UNIVERSITY

Мета роботи - провести аналіз ефективності підходів до формування сучасного викладача медичного університету.

Основна частина. У статті висвітлено діяльність навчально-тренінгового центру для викладачів з метою підвищення професійної, мовної компетентності та володіння сучасними інноваційними технологіями навчання, що має важливе значення для підвищення ефективності освітнього процесу в університеті. Наступним етапом $є$ впровадження в освітній процес інтерактивних платформ “OfficeMix” та “Forms”, що дасть змогу прозорого моніторингу процесу підготовки студентів до ліцензійних іспитів “Крок”.

Висновок. Проведений аналіз дозволяє стверджувати, що у формуванні сучасного викладача медичного університету важливе місце належить навчально-тренінговим центрам, де використовуються напрямки з підвищення професійної, мовної компетенції та володіння інноваційними методами навчання.

Ключові слова: освітній процес; навчально-тренінговий центр; професійна освіта викладача.

The aim of the work - to conduct an analysis of the effectiveness of approaches to the formation of a modern lecturer of medical university.

The main body. The article discusses the activity of the training and educational center for teachers for the purpose of improving professional and language competence and possessing modern innovative teaching technologies that are important for increasing the efficiency of the educational process at the university. The next step is to introduce the "OfficeMix" and "Forms" interactive platforms into the educational process, which will allow for transparent monitoring of the process of preparing students for the license examinations "Krok".

Conclusion. The analysis makes it possible to assert that in the formation of a modern teacher of a medical university an important place belongs to training and training centers, where the directions for increasing professional, linguistic competence and knowledge of innovative teaching methods are used.

Key words: educational process; training and educational center; professional education of a teacher.

Вступ. Відповідно до ст. 58 Закону України “Про вищу освіту”, науково-педагогічний працівник (далі - НПП) зобов'язаний забезпечувати викладання на високому науково-теоретичному і методичному рівні навчальних дисциплін відповідної освітньої програми за спеціальністю.

(C) М. М. Рожко, Г. М. Ерстенюк, В. В. Капечук та ін.
Для здійснення покладених завдань НПП необхідне постійне підвищення професійного рівня, педагогічної майстерності, наукової кваліфікації.

Враховуючи зміну парадигми освітнього процесу в підготовці медичних (фармацевтичних) кадрів, викладач університету повинен володіти інноваційними технологіями, удосконалювати методики 
викладання, орієнтовані на високу професійну компетентність фахівця в галузі охорони здоров’я. Однією із нагальних вимог, відповідно до чинної законодавчої бази України, викладач закладу вищої освіти повинен вдосконалювати знання з іноземної мови, що дозволить використовувати досягнення світової науки і практики, брати активну участь у міжнародних програмах і стажуваннях, наукових форумах тощо.

Враховуючи виклики часу, сучасні вимоги і тенденцію, в Державному вищому навчальному закладі “Івано-Франківський національний медичний університет” (далі - ДВНЗ “ІФНМУ”) створено навчально-тренінговий центр для підвищення професійної майстерності викладачів.

Мета роботи - провести аналіз ефективності підходів до формування сучасного викладача медичного університету.

Основна частина. Участь ДВНЗ “ІФНМУ” в проекті “Tempus MUMEENA” дозволила модернізацію існуючого психолого-педагогічного курсу підготовки молодих викладачів у навчально-тренінговому центрі (далі - НТЦ) для підвищення професійної майстерності викладачів. Модернізація включала такі моменти, як:

- навчання в малих групах;

- формування груп за професійним профілем;

- оцінка якості навчання;

- охоплення великої аудиторії викладачів впродовж навчального року.

Ефективна робота в НТЦ для викладачів забезпечується завдяки новітньому обладнанню (смартдошки, персональні комп’ютери тощо). НТЦ здійснюють підготовку викладачів у трьох напрямках: 1) підвищення професійної майстерності молодих викладачів; 2) іноземні мови для професійного спілкування; 3) інтерактивні методи в підготовці медичного університету.

На початку кожного навчального року, згідно $з$ поданими кафедрами заявками, формуються групи терапевтичного, хірургічного, стоматологічного та теоретичного профілю. Найбільший інтерес серед слухачів викликають теми, що стосуються проведення практичних занять, правильного ведення навчально-звітної документації та роботи в НТЦ для студентів, які розміщені на профільних кафедрах. Для формування клінічного мислення у студентів і оволодіння практичними навичками частину занять з молодими викладачами проводять доценти і професори університету на базі навчально-практичних центрів (далі - НПЦ) для студентів. Під час занять у НПЦ для студентів молоді викладачі вдосконалюють свою професійну майстерність. Слухачі, які успішно закінчили цикл, отримують сертифікат.

Модернізація методологічної освітньої парадигми, задекларована в Болонській конвенції та Державній національній програмі “Освіта: Україна XXI століття”, не можлива без ефективного підвищення лінгвістичного рівня працівників освітньої галузі.

Вільний вибір мови навчання іноземними громадянами диктує, у свою чергу, необхідність суттєвого вдосконалення навичок володіння іноземними мовами (і передовсім - англійською) викладацького складу як гуманітарних, так і профільних кафедр. До того ж ідеться про опанування не лише так званої General English, а й Academic English, тобто ділової (професійної) іноземної мови, якою необхідно забезпечувати освітній процес. Виходячи 3 цього, в НТЦ з 2013 року запрацював напрямок “Іноземні мови для професійного спілкування", навчання з якого забезпечує кафедра мовознавства ДВНЗ “ІФНМУ”, завдання якого:

- подолання психологічного бар’єра слухачів у процесі спілкування іноземною мовою (англійською, німецькою, французькою, польською);

- вдосконалення мовних навичок викладачів університету, які проводять заняття англійською мовою;

- задоволення потреб слухачів щодо оволодіння професійним термінологічним словником та його застосування в процесі реальної комунікації;

- формування у слухачів навичок реферування фахових статей, пошуку інформації в іншомовних джерелах, ведення кореспонденції, підготовка доповідей і рефератів іноземною мовою. Цей курс навчання передбачає 60 год практичних занять та 80 год самостійної роботи, підсумковий контроль у формі тестів і творчого завдання. Повна програма передбачає дворічний курс навчання.

Більшість груп першого року навчання займається за програмою “General Medicine”. Групи другого року навчання формуються відповідно до вузькоспеціалізованого принципу професійної ділової мови, тобто профілю кафедр, працівники яких $є$ слухачами НТЦ. Незалежно від року навчання, при доборі програм обов'язково враховується первинний рівень володіння іноземною мовою (початковий, базовий чи середній), засвідчений слухачем під час вступного тестування.

Починаючи з 2014 року, в НТЦ поетапно впроваджувалися програми з вивчення різних іноземних 
мов: англійської, німецької, французької та польської. Станом на сьогодні напрямок удосконалення професійних іноземних мов має з усіх вищеперелічених циклів програми дворічного навчання.

Розширення переліку мов, які вивчаються в НТЦ, зумовлене необхідністю забезпечити високий рівень навчальної, наукової та власне професійної мобільності викладачів ДВНЗ “ІФНМУ”, котрі часто є учасниками міжнародних конференцій, програм обміну, закордонних стажувань, друкують статті в міжнародних виданнях тощо. Безумовно, удосконалення професійної (ділової) іноземної мови істотне також і для можливості опанування методик, репрезентованих у закордонних наукових i науково-популярних джерелах, і представлення в інших державах власних напрацювань у сфері охорони здоров'я.

Від початку роботи в НТЦ навчалося 948 осіб $з$ напрямку “Іноземні мови для професійного спілкування”. Сертифікати про успішне завершення курсу навчання з професійної англійської мови отримали 602 слухачі, $з$ німецької - 42, з французької - 19, з польської - 41 працівник. Чимало викладачів закладу виявили бажання вивчати різні іноземні мови одночасно. 14 осіб здобули сертифікати з англійської і німецької мов, 2 - з англійської і французької, 20 - з англійської і польської. 32013 до 2017 року сертифікати про початковий рівень володіння іноземними мовами отримали 127 осіб, базовий 298, середній - 279 слухачів.

На виконання рішення Вченої ради ДВНЗ “ІФНМУ” від 16.01.18 про підвищення рівня володіння англійською мовою викладачів закладу, які працюють з іноземними студентами, заплановано впровадити програму третього року навчання “Improved Medical English” для випускників НТЦ, які успішно завершили дворічний курс із циклу “Англійська мова для професійного спілкування”.

У 2017 році в НТЦ ДВНЗ “ІФНМУ” відкрито новий напрямок із підготовки працівників закладу до складання іспиту з англійської мови на рівень В2. Така структурна реорганізація НТЦ зумовлена як необхідністю входження у простір світового освітнього процесу, так і набуттям чинності наказів МОН України і постанов Кабінету Міністрів України, які регламентують порядок присвоєння вчених звань і підготовки здобувачів вищої освіти ступеня доктора філософії чи доктора наук.

Становлення напрямку екзаменаційної підготовки в НТЦ стало можливим завдяки укладено- му 10.02.17 договору про співпрацю між ДВНЗ "ІФНМУ” та Grade Education Centre (м. Київ), який $є$ єдиним в Україні платиновим тест-центром 3 проведення іспитів Cambridge Assessment English. У серпні 2017 року ДВНЗ “ІФНМУ” отримав сертифікат про статус Exam Preparation Centre від Cambridge Assessment English. Загалом за програмами екзаменаційної підготовки в НТЦ навчалися 119 працівників ДВНЗ “ІФНМУ”.

Ефективну підготовку викладачів ДВНЗ “ІФНМУ” до іспиту FCE забезпечено введенням у дію лінгафонного кабінету, обладнаного навушниками, перегородками і комп’ютерами, закуплено навчально-методичні комплекси “Compact First”, “Objective First”, “First Trainer”, “Empower”, а також регулярним проведенням методичних конференцій i Skype-консультацій спільно з представниками Grade Education Centre.

Зазначені результати підтверджують факт добре створених умов для ефективного підвищення лінгвістичної компетентності професорсько-викладацького складу ДВНЗ “ІФНМУ”, що, у свою чергу, сприятиме формуванню лікаря (викладача) європейського зразка - всебічно розвинутого, здатного сприймати й застосовувати надбання світової медицини.

Науковий прогрес не залишає осторонь й освітній процес. Тепер студентів не здивуєш порталами дистанційної освіти, проблемно-орієнтованим навчанням, але у цій погоні за освоєнням нових технологій викладачам інколи не вистачає часу на освоєння цих сучасних технологій навчання. Звичайно, практично всі викладачі у сучасних конкурентних умовах проявляють себе із найкращої сторони, коли намагаються застосовувати мультимедійний вміст під час проведення лекційних та практичних занять, однак існують сучасні інтерактивні технології, котрі можуть значно підняти рівень зацікавленості та вмотивованості як студентів, так і викладачів до процесу навчання.

Основні інтерактивні технології, котрі застосовуються в освітньому процесі, - це технології на основі WЕВ. Так, у ДВНЗ “ІФНМУ” успішно використовується комплекс “Віртуальний пацієнт” на основі платформи “OpenLabyrnth”, платформа “EDX-IFNMU”, “Office365”. Застосування цих платформ вимагає професійного володіння комп’ютером, однак виявилось, що це є проблемою для частини викладачів. 3 метою подолання цього бар’єра в НТЦ для всіх викладачів проводились 
підготовчі ознайомлювальні курси з демонстрацією основних можливостей інтерактивних платформ університету. При цьому важливими є індивідуальні форми навчання зацікавлених ННП з урахуванням рекомендацій наших колег із медичної школи “St George’s, University of London”, які пропонували залучити зацікавлених студентів старших курсів до створення інтерактивного навчального контенту кафедр. Продуктивність роботи, швидкість підготовки тестових зразків та тестових кейсів віртуальних пацієнтів виросла удвічі.

Наступним етапом $є$ впровадження в освітній процес зв'язку інтерактивних платформ “OfficeMix” та "Forms”, що дасть змогу прозорого моні-

\section{Список літератури}

1. Про вищу освіту : Закон України від 01.07.2014 року № 1556-VII. - Режим доступу : http://zakon2.rada.gov.ua/ laws/show/1556-18.

2. Нові вимоги МОН України щодо присвоєння вчених звань : наказ від 06.02.2017 року №174. - Режим доступу : http://zakon5.rada.gov.ua/laws/show/z0245-17.

\section{References}

1. Zakon Ukrainy vid 01.07.2014 № 1556-VII Pro vyshchu osvitu [Higher Education Act of Ukraine № 1556VII of July 1, 2014]. - Retrieved from: http://zakon2.rada. gov.ua/laws/show/1556-18 [in Ukrainian].

2. Nakaz, №174 (2017). Novi vymohy MON Ukrainy shchodo prysvoiennia vchenykh zvan [New requirements of the Ministry of Education and Science of Ukraine for торингу процесу підготовки студентів до ліцензійних іспитів “Крок” та виведе процес навчання на абсолютно новий цікавий рівень, де кожен викладач і студент будуть миттєво дізнаватись про ефективність своєї діяльності. Така тестова платформа вже напрацьована та готується до широкого впровадження в освітній процес.

Висновок. Проведений аналіз дозволяє стверджувати, що у формуванні сучасного викладача медичного університету важливе місце належить навчально-тренінговим центрам, де використовуються напрямки з підвищення професійної, мовної компетенції та володіння інноваційними методами навчання.

3. Медична освіта у світі та в Україні : навч. посіб. / [Ю. В. Поляченко, В. Г. Передерій, О. П. Волосовець та ін.]. - К. : Книга-плюс, 2005. - 383 с.

the awarding of academic titles]. - Retrieved from: http:// zakon5.rada.gov.ua/laws/show/z0245-17 [in Ukrainian].

3. Poliachenko, Yu.V., Perederii, V.H., \& Volosovets, O.P. (2005). Medychna osvita u sviti ta v Ukraini [Medical education in the world and in Ukraine]. Kyiv: Knyha-plius [in Ukrainian]. 